\title{
PERKARA PERCERAIAN YANG DIPUTUS DENGAN VERSTEK
}

\author{
Oleh: \\ Sanyoto
}

Fakultas Hukum Universitas Jenderal Soedirman Purwokerto

\begin{abstract}
The court changed the divorce of a model and also an announcer Andhara Early to her husband Chesa in the Islamic Court of south Jakarta. This divorce was granted by the justice of the supreme court. This case is very interesting because the accused whom his place has been known and has been called three times properly kept his mind not to attend on the court session. Although has been called properly according to the article 125 HIR/149 RBg the absent of the accused on the court session gave the authority to the judge decided his thought vertically. His thought of the decision was depended on the accusation which is proposed on the court session and was supported by the rational argumentation of accusation. The Authentication from the plaintif ascertained the judge that the rational argumentation could be proved, with the result that the judge granted the accusation of divorce. This cose showed that the process of the court meeting by the absent of the accused made the divorce went fast.
\end{abstract}

Kata Kunci : cerai, Verstek

\section{A. Pendahuluan}

Artikel ini bermaksud membahas tentang gugat perceraian artis Andhara Early terhadap suaminya Chesa David Luckmansyah dengan Register No.1302/Pdt.G/Pengadilan Agama Jakarta Selat-an yang diputus secara verstek dan isinya mengabulkan gugat Penggugat. Perkara ini menarik oleh karena pihak Tergugat yang tempat tinggalnya diketahui serta telah dipanggil secara patut sampai tiga kali tetap tidak mau hadir kepersidangan.

Pemeriksaan perkara perdata pada kondisi yang umum dimulai dari adanya surat gugatan, kemudian oleh Pengadilan diperintahkan untuk melakukan Mediasi dalam waktu 22 hari maksimal 30 hari. Bila langkah tersebut tidak berhasil maka pada sidang berikutnya tergugat di-berikan kesempatan untuk menjawab atas gugatan yang ditujukan padanya, kemudian Penggugat memberikan replik dan Tergugat memberikan duplik. Pada tahap berikutnya keduanya saling membuktikan dalil gugatan dengan alat-alat bukti serta tergugat membuktikan dalil sangkalan/bantahannya dengan alat-alat bukti. Bila tahap itu selesai selanjutnya para pihak membuat kesimpulan akhir dan bila para pihak tidak ada lagi yang ingin dikemukakan, maka hakim akan menjatuhkan putusan.

Majelis hakim dalam memberikan putusan sudah barang tentu harus benar-benar menciptakan kepastian hukum dan adil serta memberikan kemanfaatan, sehingga dalam hal ini mereka harus benar-benar mengetahui duduk perkara yang sebenarnya dan peraturan hukum yang akan diterapkan baik peraturan hukum yang tertulis dalam peraturan perundang-undangan maupun peraturan hukum tidak tertulis atau hukum adat.

Putusan hakim diartikan sebagai suatu pernyataan yang oleh hakim sebagai pejabat Negara yang diberi wewenang untuk itu, di ucapkan di persidangan dan bertujuan untuk mengakhiri atau menyelesaikan suatu perkara atau sengketa antara para pihak. ${ }^{1}$ Selain putusan, diucapkan pula pernyataan yang di tuangkan dalam bentuk tertulis dan kemudian diucapkan dalam persidangan yang dihadiri para pihak dan dalam sidang yang terbuka untuk umum.

Putusan verstek sebagaimana diatur pada pasal 125 Herziene Indonesis Reglemen (HIR)

\footnotetext{
1 Sudikno Mertokusumo, 2002, Hukum Acara Perdata Indonesia, Yogyakarta: liberty cetakan keenam, hlm. 202
} 
atau Pasal 149 Reglement Buitengewesten (RBG) dijatuhkan oleh hakim dalam hal tergugat/kuasanya yang telah dipanggil secara patut (ehoorlijke opgeroepend) tidak hadir pada sidang yang telah ditentukan meskipun telah dipanggil secara patut. Verstek adalah merupakan pernyataan hakim bahwa Tergugat yang sudah dipanggil secara patut tidak hadir.

Perceraian yang merupakan tindakan yang seharusnya dihindari dan dapat dicegah, oleh karena perkawinan yang putus dengan cara itu tidak menyenangkan bagi semua pihak, tidak hanya suami, istri, dan anak-anak bila ada tetapi juga bagi keluarga kedua belah pihak. Perkawinan yang tidak harmonis bila dibiarkan berlarut-larut maka akibatnya juga tidak baik, maka Undang-Undang Perkawinan No.1 Tahun 1974 penjelasan Pasal 39 ayat 2 dan Peraturan Pemerintah No. 9 Tahun 1975 Pasal 19 diatur alasan yang dapat dipergunakan untuk memutuskan perkawinan dengan perceraian :

a. Salah satu pihak berbuat zina atau menjadi pemabuk, pemadat, penjudi, dan lain sebagainya yang sukar disembuhkan.

b. Salah satu pihak meninggalkan pihak yang lain selama 2 (dua) tahun berturut-turut tanpa izin pihak lain dan tanpa alasan yang sah atau karena hal lain di luar kemampuannya ;

c. Salah satu pihak mendapat hukuman penjara 5 (lima) tahun atau hukuman yang lebih berat setelah perkawinan berlangsung;

d. Salah satu pihak melakukan kekejaman atau penganiayaan berat yang membahayakan pihak yang lain;

e. Salah satu pihak mendapat cacad badan atau penyakit dengan akibat tidak dapat menjalankan kewajib-annya sebagai suami istri;

f. Antara suami dan istri terus menerus terjadi perselisihan dan pertengkaran dan tidak ada harapan akan hidup rukun lagi dalam rumah tangga.

Dalam Kompilasi Hukum Islam (KHI) Pasal 116 menambahkan 2 (dua) alasan perceraian:

a. Suami melanggar taklik-talak,

b. Peralihan agama atau Murtad yang menyebabkan terjadinya ketidakrukunan dalam rumah tangga.
Gugat perceraian diajukan ke Pengadilan yang berwenang sesuai kompetensi dan pemeriksaan perkara menurut asasnya dilakukan dalam sidang yang terbuka umum kecuali undang-undang menentukan lain, serta kedua belah pihak harus diperlakukan sama. Hal ini mengandung arti bahwa pihak-pihak yang berperkara harus sama-sama diperhatikan, berhak atas perlakuan yang sama dan adil serta masing harus diberi kesempatan untuk memberikan pen-dapatnya (audi alteram partem).

Pemeriksaan perkara oleh hakim harus objektif dan tidak memihak, serta dalam memutus harus memuat alasan-alasan putusan yang dijadikan dasar mengadili. Alasan-alasan atau argumen-tasi itu dimaksudkan sebagai pertanggungjawaban hakim terhadap masyarakat sehingga mempunyai nilai objektif. Menurut yurisprudensi Mahkamah Agung menetapkan bahwa putusan yang tidak lengkap atau kurang cukup pertimbangan merupakan alasan untuk kasasi dan dapat untuk membatalkan putusan. ${ }^{2}$

Setelah gugatan diajukan ke pengadilan yang berwenang sesuai dengan kompetensinya, selanjutnya Penggugat dan Tergugat dipanggil secara tertulis untuk menghadiri persidangan. Ketidak hadiran Tergugat pada persidangan pada hari dan tanggal yang telah ditentukan meskipun telah dipanggil secara, patut maka perkara itu dapat diputus secara verstek oleh hakim Perkara perceraian yang diputus secara verstek sesuai syarat ketentuan Pasal 125 $\mathrm{HIR} / 149 \mathrm{RBg}$ mempercepat penyelesaian perkawinan yang bermasalah, akan tetapi memberi pengaruh negatif terhadap cita-cita UndangUndang Perkawinan yang pada azasnya mempersulit terjadinya perceraian. Bagaimanakah sikap hakim dalam menghadapi fenomena tersebut?

\section{B. Pembahasan}

\section{Pengertian Verstek, Syarat-syarat putusan} Verstek

Perkara di pengadilan secara umum dapat di bedakan menjadi dua yaitu perkara yang menurut ketentuan hukum materiil harus

\footnotetext{
2 Moh Taufik Makarao, 2004, Pokok-pokok Hukum Acara Perdata, Jakarta: Rineka Putra, hlm. 6
} 
diajukan dengan permohonan dan perkara yang harus di-ajukan dengan tuntutan/gugatan. Kata perkara menurut pengertian yang umum adalah suatu persoalan yang dihadapi subjek hukum untuk diselesaikan secara hukum. Dalam pengertian hukum acara perdata perkara diartikan sebagai suatu masalah/persoalan hak yang sedang dipersengketakan, oleh para pihak di ajukan ke pengadilan bila tidak dapat diselesaikan secara musyawarah mufakat dan mereka menuntutnya agar diputus dengan harapan memperoleh suatu keadilan, memperoleh kepastian dan manfaat hukum. Bila suatu hak sudah dipersoalkan, maka disana para pihak mulai mempersoalkan kewajiban yang dilalaikan atau bicara kerugian atas peristiwa atau suatu hubungan hukum yang tidak berjalan sebagaimana mestinya. Artikel ini mengulas perkara perdata yang mengandung sengketa yang diajukan dengan gugatan saja.

Menurut ketentuan hukum acara perdata yang berlaku sampai saat ini yang merupakan hukum peninggalan Belanda yang berupa Herziene Indonesisch Reglement (HIR S.1848 No.16, S.1941 No.44) dan Rechreglement Buitengewesten (RBG S.1927 No. 227) serta Reglement op de Burgerlijke rechtsvordering (RV S.1847 no. 1847, S.1849 No. 63), bahwa bila Tergugat yang telah dipanggil secara patut untuk hadir ke persidangan pada hari yang telah ditentukan sesuai dengan Pasal 121 ayat 1 HIR/145 RBG maka hakim dapat memutuskan perkara itu dengan verstek. Pemanggilan kepada pihak-pihak yang berperkara dilakukan oleh jurus sita atau juru sita pengganti dengan menyerahkan surat panggilan/relaas. Pada waktu memanggil Tergugat, harus diserahkan juga sehelai salinan surat gugatan, dengan memberitahukan bahwa kalau ia mau, boleh menjawabnya secara tertulis (Pasal 121 ayat (2)/145 ayat (2) RBG). Pemanggilan yang dilakukan harus bertemu dan berbicara langsung dengan orang yang dipanggil di tempat kediaman/tempat tinggal (Pasal 118 HIR/142 RBG). Bila tidak bertemu dengan orang yang dimaksud maka relaas harus disampaikan kepada Kepala Kelurahan/Kepala Desa yang wajib dengan segera memberitahukan panggil-an itu
(Pasal 390 ayat 1 HIR/718 RBG). Bila yang dipanggil bertempat tinggal di luar daerah hukum pengadilan yang memeriksa perkara, maka panggilan dilakukan melalui Ketua pengadilan yang daerah hukumnya meliputi tempat tinggal yang dipanggil tersebut. Relaas panggilan kemudian dikirimkan kepada pengadilan negeri yang memeriksa perkara ${ }^{3}$

Juru sita setelah melakukan panggilan harus menyerahkan risalah/relaas panggilan kepada hakim yang memeriksa perkara yang merupakan bukti bahwa panggilan telah benarbenar dilakukan. Hal ini sangat penting bagi hakim, karena apabila pihak-pihak telah di panggil secara patut, dan kemudian tanpa alasan yang sah tidak hadir pada persidangan yang telah ditentukan, maka hakim dapat menjatuhkan putusan (karena ketidak hadiran penggugat atau tergugat). ${ }^{4}$ HIR/RBG memang tidak mewajibkan Tergugat untuk datang ke persidangan; suatu Einlassungspflicht, memang tidak dikenal. 5

Pasal 125 HIR/149 Rbg mengatur acara bij verstek dimana di luar hadirnya tergugat yang telah dipanggil secara patut (behoorlijk opgeroepend) tidak hadir pada sidang yang ditentukan meski-pun telah dipanggil secara patut. Adapun bunyi Pasal 125 HIR/ 149 RBg selengkapnya sebagai berikut :

1) Jika tergugat tidak datang pada hari perkara itu akan diperiksa, lagi pula ia tidak menyuruh orang lain menghadap sebagai wakilnya, meskipun telah di panggil dengan patut, kecuali kalau nyata pada pengadilan negeri bahwa tuntutan itu melawan hak atau tidak beralasan,

2) Akan tetapi jika si tergugat di dalam surat jawabannya yang tersebut pada Pasal $121 \mathrm{HIR} / 145 \mathrm{RBg}$ mengemukakan eksepsi (penangkisan) bahwa pengadilan negeri tidak berkuasa akan memeriksa perkaranya, maka meskipun ia sendiri atau wakilnya tidaklah datang, wajiblah pengadilan negeri

\footnotetext{
3 Subekti, 1977, Hukum Acara Perdata, Jakarta: Bina Cipta, hlm. 47

4 Riduan Syahrani, 2000, Buku materi dasar Hukum Acara Perdata, Bandung : Citra Aditya, hlm. 49

5 Sudikno Mertokusumo, 2002, Hukum Acara Perdata Indonesia, Yogyakarta: Liberty, hlm. 101
} 
memberi putusan tentang eksepsi itu, sesudahnya di dengarnya orang yang menggugat itu, hanya jika eksepsi itu tidak dibenarkan, maka pengadilan negeri akan memutuskan pokok perkara tersebut.

3) Jika tuntutan diterima (disahkan) maka atas perintah ketua diberitahu-kan putusan itu kepada orang yang di kalahkan serta diterangkan pula kepadanya bahwa ia berhak mengajukan perlawanan putusan tidak hadir di muka majelis pengadilan itu juga dalam waktu dan dengan cara yang ditentukan Pasal 129 HIR/153 RBg.

4) Panitera pengadilan menuliskan di bawah putusan tak hadir itu siapa yang diperintahkan menjalankan pekerjaan itu dengan apa yang diterangkan orang itu tentang hal itu, baik dengan surat maupun dengan tulisan. ${ }^{6}$

Kata-kata kunci yang memerlukan perhatian dalam pemeriksaan di luar hadirnya tergugat adalah :

a. Tergugat/Kuasanya tidak datang pada persidangan yang ditentukan.

b. la telah dipanggil dengan patut (behoorlijk opgeroepend).

c. Gugatan tersebut tidak melawan hukum (onrechtmatieg daad) atau cukup beralasan (gegrond). ${ }^{7}$

Verstek adalah merupakan pernyataan hakim bahwa seorang Tergugat yang sudah dipanggil secara patut, tidak hadir sedang menurut hukum acara ia harus hadir. Seorang yang datang pada hari sidang pertama, kemudian pada hari sidang berikutnya tidak hadir, maka tidak akan mendapat keputusan Verstek, akan tetapi perkara akan diperiksa dengan acara biasa sebagai perkara Contra-dictoir (op tegenspraak). ${ }^{8}$ Tentang kapan boleh dijatuhkan putusan verstek terdapat 2 pendapat yakni :

a. Harus dijatuhkan pada hari sidang yang pertama dengan mendasarkan pada kata-

6 Susilo,1979, RIB/HIR dengan penjelasan, Bogor : Politea, $\mathrm{hlm} .83$

7 Mahkamah Agung, 2003, Bunga Rampai Makalah Hukum Acara Perdata, Proyek Pendidikan dan Pelatihan Teknis Fungsional Hakim dan Non Hakim, Jakarta, hlm. 145

8 Supomo, 1984, Hukum Acara Perdata Pengadilan Negeri, Jakarta: Fasco, hlm. 44 kata "ten dage diende" dalam Pasal 125 $\mathrm{HIR} / 149 \mathrm{RBG}$.

b. Ten dage diende" dapat pula diartikan "ten dage dat de zaak dient "yang berarti tidak hanya pada sidang yang pertama saja karena Pasal 126 HIR/150 RBG memberi kelonggaran untuk dipanggil sekali lagi. ${ }^{9}$

Majelis hakim pengadilan agama Jakarta Selatan dalam memutus perkara mengikuti pendapat yang kedua dengan bertitik tolak dengan menafsirkan secara acontrario ketentuan Pasal 126 HIR/150 RBG. karena menurut pasal tersebut kalau Penggugat tidak hadir setelah dipanggil secara patut pada sidang yang pertama maka Majelis hakim menunda persidangan dengan memerintahkan kepada panitera agar dipanggil sekali lagi secara resmi oleh juru sita.

Dengan kata lain, penundaan persidangan oleh hakim dengan memperhatikan kemungkinan ketidak hadiran karena sesuatu hal di luar kemampuannya. Sedangkan mengapa gugatan penggugat dikabulkan pertimbangan hukumnya karena tergugat telah dipanggil secara patut tidak hadir dan penggugat berhasil membuktikan dalil gugatannya di persidangan dengan alat-alat bukti yang sah, bahwa perkawinan (rumah tangga) antara Penggugat dan Tergugat sudah tidak mungkin diperbaiki lagi serta dalil gugatan (rechtsfeiten) yang meliputi baik feitelijke maupun rechtelijke beweringen dengan petitum (eisch)/tuntutan/apa yang di minta penggugat ada dasar hukumnya dan beralasan, maka majelis hakim memutuskan dengan verstek dengan isi mengabulkan gugatan penggugat untuk seluruhnya.

Syarat-syarat hakim menjatuhkan putusan Vestek dapat dilihat dari ketentuan Pasal 125 HIR/149 RBg yakni :

a. Tergugat/Para Tergugat tidak hadir semuanya di persidangan pada hari yang di tentukan,

b. Tergugat/Para Tergugat juga tidak mengirimkan kuasa/wakilnya yang sah,

c. Tergugat/Para Tergugat telah dipanggil dengan sepatutnya,

9 Ibid, hlm.102 
d. Petitum tidak melawan hak, dan

e. Petitum beralasan.

\section{Kemungkinan Isi Putusan Verstek.}

Isi putusan Verstek menurut Lilik Mulyadi ada 4 (empat) kemungkinan:

a. Surat Gugatan Penggugat/Para Penggugat di kabulkan seluruhnya

b. Surat Gugatan Penggugat/Para Penggugat di kabulkan untuk sebagian.

c. Surat Gugatan Penggugat/Para Penggugat di tolak,

d. Surat gugatan Penggugat/Para Penggugat di nyatakan tidak dapat diterima (Niet Onvant kelijke Verklaard (N.O) ..$^{10}$

Hakim mengabulkan surat gugatan Penggugat/Para Penggugat untuk seluruhnya yakni apabila keseluruhan syarat-syarat Pasal 125 HIR/149 RBg dipenuhi (a s.d. e), sedang akan memutus mengabulkan gugatan untuk sebagian yaitu apabila syarat (a) s.d. (d) dipenuhi sedang syarat (e) dari keseluruhan petitum yang di ajukan dalam surat gugatan ada yang dikabulkan dan ada yang ditolak karena tidak beralasan dan berdasarkan hukum.

Pada putusan hakim yang isinya menyatakan surat gugatan Penggugat/para Penggugat ditolak pertimbangannya karena syarat a sd c dipenuhi tetapi syarat $d$ dan e tidak yaitu petitumnya ternyata melawan hak atau tidak beralasan, sedang putusan hakim yang menyatakan surat gugatan Penggugat/Para Penggugat tidak dapat diterima (Niet Onvant kelijke Verklaard) hal ini pertimbangannya karena syarat a sampai dengan c dipenuhi tetapi pada surat gugatan penggugat/para penggugat ternyata ada kesalahan formal di dalamnya, misalnya subjek dan kualitas orang yang mengajukan gugatan adalah orang yang tidak berhak atau dapat pula karena surat gugatan ditandatangani oleh kuasa/wakil yang tidak mempunyai surat kuasa khusus.

Tergugat tidak hadir ke persidangan boleh jadi menganggap gugatan penggugat mengada-ada, tidak punya alasan dan kadang-

\footnotetext{
${ }^{10}$ Lilik Mulyadi,1999, Hukum Acara Perdata menurut Teori dan Praktek Peradilan Indonesia, Jakarta : Djambatan, hlm. 126 sd 132
}

kadang karena merasa tidak mempunyai hubungan hukum atau tidak terkait dengan pokok persoalan yang sedang dipersengketakan. Alasan yang demikian tidak dapat menjadi dasar yang sah untuk mengelak panggilan untuk hadir dipersidangan, kecuali kalau ada alasan yang sah, ditujukan untuk menunda, namun proses pemeriksaan menunggu sampai tergugat hadir.

\section{Hakim bersikap hati-hati dan bijaksana dalam menjatuhkan bijverstek dan reaksi masyarakat atas putusan hakim. \\ Menentukan penilaian terhadap panggilan} patut yang telah dilaksanakan oleh jurusita hakim harus cermat karena hal itu akan dapat mengembangkan fair trial yang diharapkan melahirkan putusan yang berkeadilan baik secara moral, sosial dan yuridis. Relaas panggilan yang patut/sah (behonlijk) dalam suasana keterbukaan dan perlindungan hak asasi manusia harus benar-benar sampai ke yang berperkara, bila hanya mendasarkan pada hal yang formal maka putusan yang dijatuhkan dengan verstek di dalamnya mengandung kelemahan. Akibatnya bila putusan memperoleh kekuatan hukum tetap dan diajukan permohonan eksekusi akan muncul persoalan baru dimana tergugat meng-ajukan perlawanan atau Verzet. Dengan diajukan Verzet secara formal perkara menjadi mentah kembali. Hal yang demikian bagi pihak-pihak yang tidak memahami hukum acara akan memberi komentar yang negatif terhadap lembaga peradilan.

Persoalan setuju atau tidak setuju dengan putusan hakim adalah hal wajar. Meski demikian ketidaksetujuan kalangan tertentu atau publik terhadap hal itu sama sekali tidak mempengaruhi sah dan mengikatnya putusan hakim. Dalam hukum acara berlaku asas resjudicata proveritate habetur. Makna dikabulkannya gugatan penggugat dengan verstek adalah sah dan mengikat, kecuali si suami (Chesa) mengajukan perlawan-an, bila hal itu tidak dilakukan maka putusan hakim yang dijatuhkan memperoleh kekuatan hukum tetap. Pendapat atau komentar yang berupa pernyataan bahwa putusan hakim tidak adil bukanlah pernyataan yang tepat, akan lebih tepat yang tidak setuju 
atas putusan hakim mengatakan "Putusan hakim tidak sesuai dengan perasaan keadilan saya“.. ${ }^{11}$ Rasa keadilan tiap orang amat plural. Menurut Wernen Menski ajaran tentang Trianguler Concept seluruh konsep tentang sistem hukum baik dari negara, anggota masyarakat, moralitas dimana dan kapanpun tidak ada keragaman yang absolut dalam hukum dan keadilan.

Tujuan orang menyelesaikan masalah hukum ke pengadilan sebagai benteng terakhir adalah untuk tidak hanya mencari perlindungan hukum semata atas persoalan yang dihadapi tetapi juga merupakan merupakan perwujudan dari kesadaran untuk me-matuhi hukum bukan dengan tindakan main hakim sendiri. Jika ia ingin memaksakan keinginan dan kepentingan untuk dituangkan sebagai putusan hakim dengan cara meski harus mengobrak-abrik tatanan dan prosedur hukum adalah merupakan perbuatan yang naif.

\section{Penutup}

Berdasarkan uraian tersebut diatas dapat disimpulkan bahwa putusan verstek dijatuhkan Hakim bila ketentuan Pasal 125 HIR/149 RBg syarat (a) sampai dengan (e) dipenuhi sedang isi putusannya sangat tergantung pada hasil pembuktian dari Penggugat dan secara faktual proses pemeriksaan perkara sampai diputus jauh lebih cepat. Pengaruhnya bagi suami dan istri adalah sangat positip karena perceraian selesai lebih cepat serta dapat mencegah tindakan yang dapat merusak sendi-sendi kehidupan keluarga dalam negara hukum yang berdasarkan Pancasila, meski dari aspek hukum perkawinan sebagai hukum materiil tujuan yang dicita-citakan tidak terwujud.

Peran Hakim sebagai penegak hukum yang bijaksana dalam peradilan yang modern bukan hanya sebagai menegakan keadilan yang "substantif" saja, tetapi bersamaan/berbarengan dengan keadilan prosedural" (yang sesuai dengan hukum acara yang berlaku).

\section{Daftar Pustaka}

\footnotetext{
${ }^{11}$ Achmad Ali, 2008, Reaksi Proporsional atas Putusan hakim, Kompas Opini Jumat 16 Januari,hlm. 6
}

Arto, Mukti. 1996. Praktek Perkara Perdata Pada Pengadilan Agama. Yogyakarta: Pustaka Pelajar;

Harahap, Yahya Muhamad. 2005. Hukum Acara Perdata Tentang Gugatan, Penyitaan, Pembuktian dan Putusan Pengadilan. Jakarta: Sinar Grafika;

Hamid, Andy Tahir. 1986. Hukum Acara Perdata Serta Susunan dan kekuasaan Pengadilan. Surabaya: Bina Ilmu;

Mertokusumo, Sudikno. 2002. Hukum Acara Perdata Indonesia. Yogyakarta: Liberty;

-..-1999, Penemuan hukum Sebuah Pengantar. Cetakan kedua. Yogyakarta: Liberty;

Mulyadi, Lilik. 1999. Hukum Acara Perdata menurut Teori dan Praktik Peradilan di Indonesia. Jakarta: Djambatan;

Manan, Abdul. 2005. Penerapan Hukum Acara Perdata di Lingkungan Peradilan Agama. Jakarta: Kencana Pranada Media Group;

Muhamad, Abdulkadir. 2000. Hukum Acara Perdata Indonesia. Bandung: Citra Aditya Bakti;

Mahkamah Agung. 2003. Bunga Rampai Makalah Hukum Acaara Perdata, Proyek Pendidikan dan Pelatihan Teknis Fungsional hakim dan Non Hakim. Jakarta: Mahkamah Agung;

Makarau, Mohamad Taufik. 2004. Pokok Pokok Hukum Acara Perdata. Jakarta: Rineka Cipta;

Syahrani, Riduan. 2000. Buku Materi dasar Hukum Acara Perdata. Bandung: Citra Aditya Bakti;

Subekti. 1977. Hukum Acara Perdata. Jakarta: Bina Cipta;

Sutantio, Retnowulan. 1983. Hukum Acara Perdata dalam Teori dan Praktek, Bandung: Alumni;

Supomo. 1984. Hukum Acara Perdata Pengadilan Negeri. Jakarta: Fasco.

\section{Artikel}

Ali, Achmad. 2009. Reaksi Proporsional atas Putusan Hakim. Kompas 16 Januari 2009. 
Perkara Perceraian

yang Diputus dengan Verstek 